\title{
The Prognostic Value of G1 Cyclins, p21 and Rb Protein in Patients With Colon Cancer
}

\author{
PANTELIS PALAIOLOGOS ${ }^{1}$, DIMOSTHENIS CHRYSIKOS ${ }^{2}$, \\ STAMATIOS THEOCHARIS ${ }^{3}$ and GREGORY KOURAKLIS ${ }^{1}$ \\ ${ }^{1}$ 2nd Department of Propedeutic Surgery, Medical School, \\ National and Kapodistrian University of Athens, Athens, Greece; \\ ${ }^{2}$ University Department of Surgery, General and Oncologic Hospital of Kifissia 'Agii Anargiri', Athens, Greece; \\ ${ }^{3}$ First Department of Pathology, Medical School, National and Kapodistrian University of Athens, Athens, Greece
}

\begin{abstract}
Background/Aim: Cyclins D1 and E play different roles in the cell cycle. Cyclin E promotes chromosome instability, whereas cyclin D1 regulates apoptosis of cells. This study evaluated the prognostic significance of G1 cyclins, p21 and $\mathrm{pRb}$ in tumor proliferation. Patients and Methods: A total of 102 patients with colon cancer were operated on and staged according to TNM. Follow-up was 2 to 68 months (mean 38.3 \pm 16.7 months). Expression of cyclin E and DI were evaluated using immunohistochemistry. Results: Levels of cyclin $E$ expression were correlated with cyclin DI expression ( $p=0.038), p 21$ expression $(p=0.047)$, and $p R b$ expression $(p=0.004)$. The 5-year survival rate along with prognosis of patients with advanced stage $(I I I, I V)$ colon cancer and cyclin D1 positive tumors, were significantly worse $(p=0.009)$. Statistically significant association was observed between tumor proliferative capacity Ki-67, cyclin DI $(p=0.009), p R b(p=0.031)$ and $p 21(p=0.050)$. Conclusion: Cyclin D1 is highly expressed in advanced stage colon cancer patients, implying a potential prognostic value.
\end{abstract}

Colorectal cancer (CRC) is one of the main challenges for public health representing the third most common cancer worldwide, following prostate and lung cancer in males and breast and lung cancer in females $(1,2)$. According to the World Health Organization, in 2018 there were 1.8 million colorectal cancer cases of which 861,000 resulted in death (3). In the United States, 1,762,450 new cancer cases and 606,880 cancer deaths are projected to occur in 2019 (4). The annual estimation of new cases diagnosed with large

Correspondence to: Dimosthenis Chrysikos MD, MSci, Ph.D., Gortynias 9, 16561 Athens, Greece. Tel: +30 6973063590, e-mail: dixrys@yahoo.gr

Key Words: Cyclin D1, cyclin E, Rb, p21, prognosis, colon cancer. bowel cancer is approximately 145,600 (4). Among these, 101,420 are colon and the remainder are rectal cancers, while CRC-related deaths are approximately 50,630.

Currently, advances in chemotherapy either as adjuvant in colon cancer, or as neoadjuvant with radiotherapy in rectal cancer, require the precise determination of the subgroup of patients which may have a survival benefit (5). In this respect, the identification of specific, early expressed biomarkers may contribute to a better prognosis of patients with intermediate grade tumors.

Cyclins and the cyclin-dependent kinases, are key regulators of the cell cycle (6). Errors in the normal process of the cell cycle result in deregulated DNA replication and mitosis (7) leading to increased resistance to apoptosis and the induction of cancer $(8,9)$. A major cell cycle regulatory point in most animal cells called the restriction point, occurs late in $G_{1}$ and controls progression from $G_{1}$ to $S(10)$. The two main aspects of cell cycle regulation are the DNA structure checkpoints, which arrest the cell cycle in response to DNA damage or incomplete replication, and the existence of the restriction point (11). Once cells have passed the restriction point, they are normally committed to proceed and divide, hence, the so called G1 cyclins have a prevailing role in promoting cell division (12). The G1-S transition of the cell cycle, is mainly regulated by cyclins D1 and E, each of them playing a different and discrete role (13). Cyclin E has been involved in various cancer cell lines (14), in breast carcinomas (15) and in about $10 \%$ of colorectal cancer cases (16). Keyomarsi et al., (1994) reported a correlation between cyclin $\mathrm{E}$ expression and advanced stage breast carcinomas, implying its potential role as a prognostic marker (17).

The retinoblastoma $(\mathrm{Rb})$ protein is a tumor suppressor, and a key negative regulator of the cell cycle (18) by suppressing $G_{1}$ phase progression (19). Rb protein is active in the early $G_{1}$ phase in its hypophosphorylated form, whereas in $\mathrm{mid} / \mathrm{late} \mathrm{G}_{1}$ phase the protein becomes 
inactivated by phosphorylation. Cyclins D1 and E, along with their catalytic partners, the cyclin-dependent kinases (cdk), are responsible for this phosphorylation of $\mathrm{pRb}$ and also regulate progression of the cell cycle from $G_{1}$ to $S$ phase (20). Moreover, p21 acts by binding cdks in the G1 phase of the cell cycle and leading to the inhibition of phosphorylation of other proteins like $\mathrm{Rb}$, necessary for cell cycle progression (21). The protein product of $\mathrm{Rb}$ leads to the inhibition of the cyclin D1 and cyclin E promoter activity by binding to E2F transcription factors. In mid-tolate $G_{1}$ phase, where $R b$ is initially phosphorylated, probably by cdk-cyclin D complexes, E2F transcription factors are produced, which promote transcription of the cyclin D1 and cyclin $\mathrm{E}$ genes (22-24). Inactivation of the $R b$ gene is involved in various types of cancers $(25,26)$, however in colorectal carcinomas loss or inactivation of $\mathrm{Rb}$ seems to be rare (27). In contrast to the fact that loss of pRb activity is observed in various tumors, other studies have depicted increased levels of $\mathrm{Rb}$ transcripts in colorectal cancer, implying a potential mitotic role of $\mathrm{pRb}(28,29)$. Moreover, increased cyclin D1 and cyclin E expression endures $\mathrm{Rb}$ phosphorylation. As a consequence, additional E2Fs are released that pursue cyclin D1 and cyclin E transcription. Overexpression of cyclin D1 or cyclin E enhances phosphorylation of $\mathrm{Rb}$ and promotes cellular proliferation suppressing pRb activity. This concept of cyclin D1 and cyclin $\mathrm{E}$ as positive regulators of cell proliferation is supported by various studies where microinjection of anticyclin D1 and E antibodies prevent cells from entering the S-phase of the cell cycle (30-32).

Overexpression of cyclin D1 or cyclin E is positively involved in carcinogenesis as increased levels of cyclin D1 and $\mathrm{E}$ have been shown to induce cell growth by shortening the duration of the G1 phase of the cell cycle $(13,32)$. Mermelshtein et al. reported a correlation between cyclins D1 and/or D2, but not cyclin D3, and TNM stage of colon carcinomas. In addition, overexpression of cyclin D2 may be strongly related to a higher TNM stage of tumors (33). In another prospective patient cohort study by Wangefjord $e t$ $a l$., it was depicted that cyclin D1 expression in colorectal cancer has a different effect in males and females. It was shown that cyclin D1 was a favorable prognostic factor in men compared to women (34). A meta-analysis in 2014, of 22 studies and a total of 4150 patients, indicated that cyclin D1 is an unfavorable prognostic factor for colorectal cancer. Cyclin D1 overexpression might be associated with a poor clinical outcome and clinical and pathological data such as age, tumor, lymph nodes and distant metastasis in colorectal cancer patients (35). Al-Maghrabi J et al. have also published that expression of cyclin D1 in colorectal carcinomas is not related to overall survival. No significant correlation with clinicopathological features was presented, except from lympho-vascular invasion (36).
We can assume that overexpression of cyclins, may not only contribute to tumorigenesis but may also have a potentially predictive role in the clinical aggressiveness of colon carcinomas. In the present study, we investigated immunohistochemically the expression of both G1 cyclins (D1 and E) in relation to Ki-67 expression, in human colon cancer specimens. The above data support that cyclins may be used as sensitive and accurate markers in the diagnosis of colorectal cancer (37). The present study aimed to identify the involvement of $G_{1}$ cyclins in the cell cycle regulation of human colon cancer cells and whether there is any prognostic significance in subgroups of patients, according to staging.

\section{Patients and Methods}

Study population. The study group consisted of 102 patients with newly diagnosed and histologically confirmed colon cancer, 60 men $(58.8 \%)$ and $42(41.2 \%)$ women. All patients enrolled, received surgical resection treatment with curative intent. The age composition of our study population was $42-94$ years with a mean age of 70.6 years. Patients with rectal cancer and those who refused follow-up were excluded from the study.

Histology and immunohistochemistry. Histology: Tissue samples were fixed in $10 \%$ formalin and embedded in paraffin A. Five $\mu \mathrm{m}$ thick paraffin sections were produced using a microtome. Dewaxed sections were stained with hematoxylin and eosin as previously described (38).

Immunocytochemistry: Sections were incubated in $10 \mathrm{mM}$ citrate buffer ( $\mathrm{pH} \mathrm{6.0)}$ ) for $15 \mathrm{~min}$, and then exposed to freshly prepared $0.3 \%$ hydrogen peroxide in methanol, for $30 \mathrm{~min}$, at room temperature (RT). Blocking was performed using blocking reagents (Snipper, Biocare Biochemicals, Walnut Creek, CA, USA), for 10 min. Sections were incubated for $1 \mathrm{~h}$, at RT, with the primary antibodies diluted in 1:100 phosphate buffered saline (PBS). Slides were the incubated with secondary biotinylated antibodies for 20 min at RT. Peroxidase-streptavidin labelling (AB Complex, Dakopatts) was performed for $20 \mathrm{~min}$, at RT. Then, the colour was developed in $0.5 \%(\mathrm{v} / \mathrm{v}) 3.3$ '-diaminobenzidine hydrochloride (DAB, Sigma, St Louis, MO, USA) in PBS containing $0.03 \%(\mathrm{v} / \mathrm{v})$ hydrogen peroxide for $2 \mathrm{~min}$. Antigens were retrieved only for $\mathrm{Ki}$ 67 , by the use of microwaves. All immunohistochemical studies were blinded to the clinical data. The primary antibodies used were: mouse (IgG1k) monoclonal antibodies anti-cyclins D1 and E (Santa Cruz Biochemicals, CA, USA), anti-human pRb (Santa Cruz Biochemicals), and anti-Ki-67 (Dakopatts, Glostrup, Denmark). Secondary antibodies included the Rodent immunoglobulins (Dakopatts) for detection of cyclin D1, cyclin E and Ki-67 and the swine anti-rabbit immunoglobulins for $\mathrm{pRb}$, and were diluted 1:200 in PBS.

Statistical analysis. We evaluated the correlation between cyclin E, cyclin D1, p21, pRb and Ki-67 expression and various clinical and pathological variables (age, location, stage and grade, lymph node metastasis, liver metastasis and vascular invasion) by using the chisquare test $\left(\mathrm{X}^{2}\right)$. Kaplan-Meier survival curves were compared using the log rank test. The effect of each potential prognostic factor 


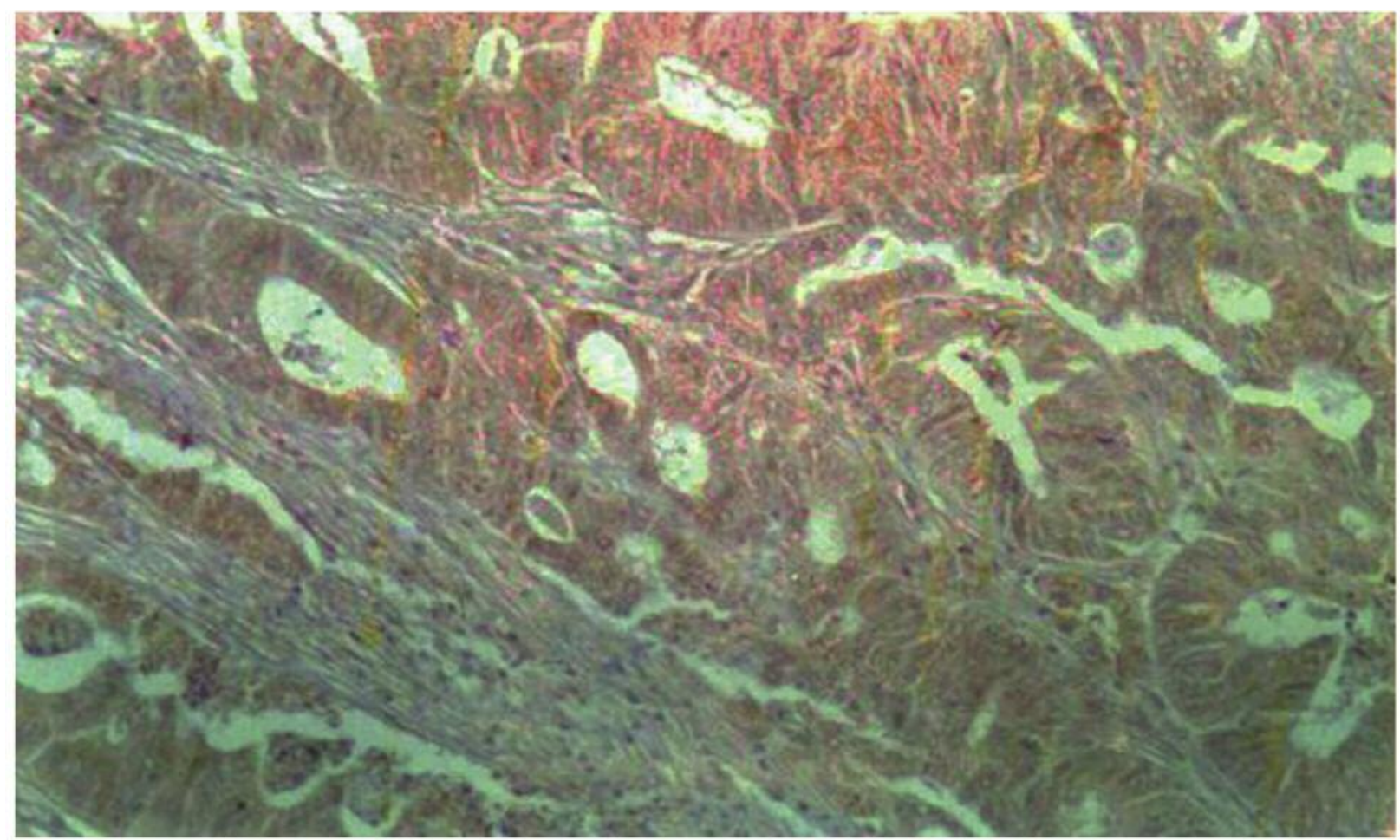

Figure 1. Section of a colon cancer specimen stained positive for Cyclin E. Magnification: $\times 20$

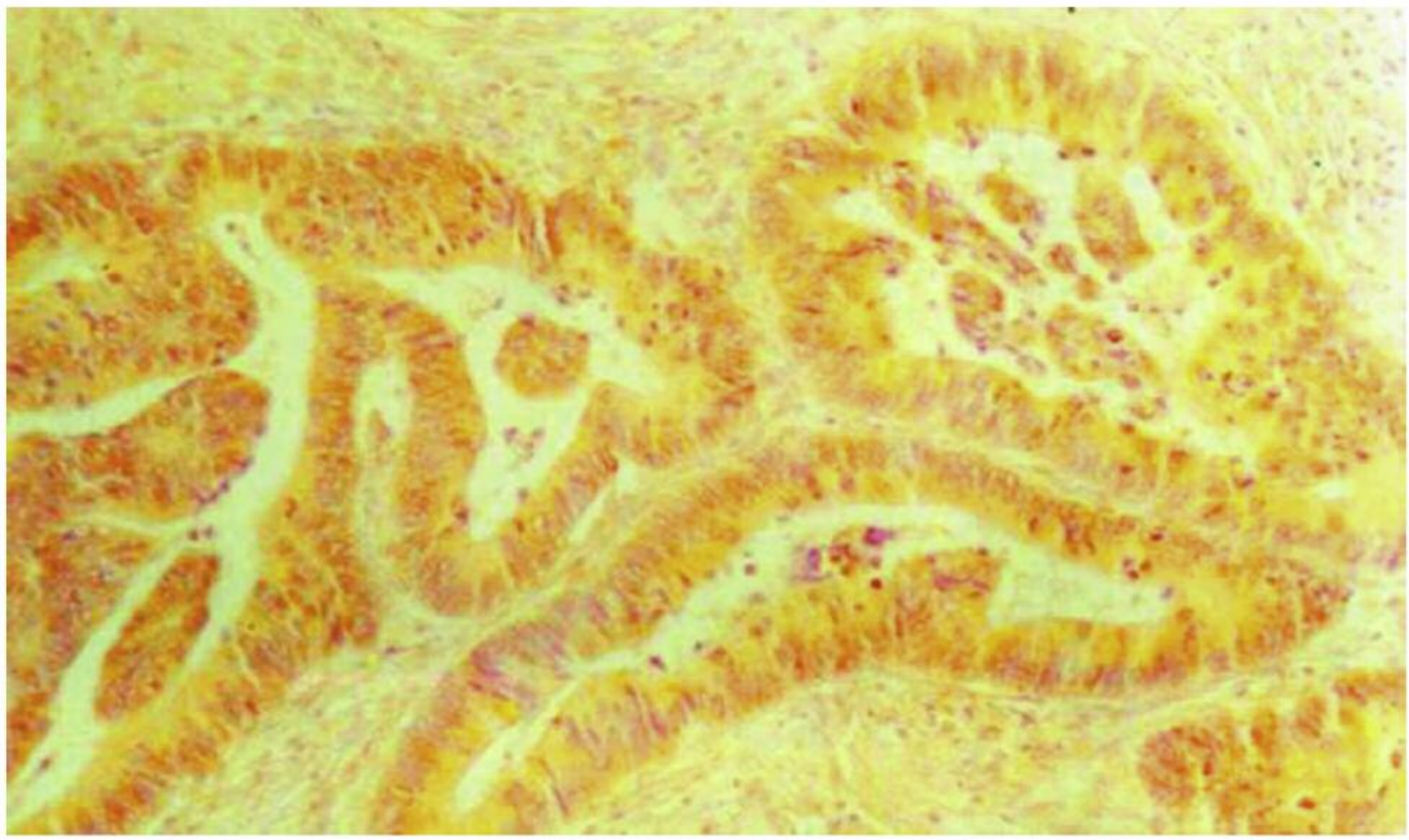

Figure 2. Section of a colon cancer specimen stained positive for $p R b$. Magnification: $\times 20$ 
Table I. The expression of cyclins D1, E, p21 and their correlation to clinical and pathologic characteristics of colon cancer ( $X^{2}$ test).

\begin{tabular}{|c|c|c|c|c|c|c|c|c|c|}
\hline & \multicolumn{2}{|c|}{ Cyclin E } & \multirow[t]{2}{*}{$p$-Value } & \multicolumn{2}{|c|}{ Cyclin D1 } & \multirow[t]{2}{*}{$p$-Value } & \multicolumn{2}{|c|}{$\mathrm{p} 21$} & \multirow[t]{2}{*}{$p$-Value } \\
\hline & $(+)$ & $(-)$ & & $(+)$ & $(-)$ & & $(+)$ & $(-)$ & \\
\hline \multicolumn{10}{|l|}{ Age } \\
\hline$<70$ years & 21 & 26 & 0.321 & 34 & 13 & 0.136 & 26 & 21 & 0.122 \\
\hline$\geq 70$ years & 30 & 25 & & 32 & 23 & & 22 & 33 & \\
\hline \multicolumn{10}{|l|}{ Gender } \\
\hline Male & 25 & 35 & 0.044 & 36 & 24 & 0.235 & 28 & 32 & 0.924 \\
\hline Female & 26 & 16 & & 30 & 12 & & 20 & 22 & \\
\hline \multicolumn{10}{|l|}{ Staging } \\
\hline $\mathrm{I}+\mathrm{II}$ & 30 & 25 & 0.321 & 36 & 19 & 0.864 & 29 & 26 & 0.215 \\
\hline $\mathrm{III}+\mathrm{IV}$ & 21 & 26 & & 30 & 17 & & 19 & 28 & \\
\hline \multicolumn{10}{|l|}{ Grade } \\
\hline Good/moderate & 39 & 43 & 0.318 & 50 & 32 & 0.110 & 40 & 42 & 0.481 \\
\hline Poor & 12 & 8 & & 16 & 4 & & 8 & 12 & \\
\hline \multicolumn{10}{|l|}{ Location } \\
\hline Proximal & 17 & 18 & 0.835 & 24 & 11 & 0.555 & 19 & 16 & 0.291 \\
\hline Distal & 34 & 33 & & 42 & 25 & & 29 & 38 & \\
\hline \multicolumn{10}{|l|}{ Lymph nodes } \\
\hline Positive & 20 & 20 & 1.000 & 24 & 16 & 0.424 & 15 & 25 & 0.120 \\
\hline Negative & 31 & 31 & & 42 & 20 & & 33 & 29 & \\
\hline \multicolumn{10}{|l|}{ Liver metastasis } \\
\hline Positive & 9 & 7 & 0.586 & 13 & 3 & 0.132 & 5 & 11 & 0.168 \\
\hline Negative & 42 & 44 & & 53 & 33 & & 43 & 43 & \\
\hline \multicolumn{10}{|l|}{ Vascular infiltration } \\
\hline Positive & 16 & 11 & 0.262 & 19 & 8 & 0.473 & 11 & 16 & 0.443 \\
\hline Negative & 35 & 40 & & 47 & 28 & & 37 & 38 & \\
\hline
\end{tabular}

on patients' overall survival was evaluated by using Cox regression analysis. Results were considered statistically significant when $p$ value was less than $0.05(p<0.05)$.

\section{Results}

Patients tumor, node, metastasis (TNM) staging classification. The total of 102 patients included in this study had been diagnosed with colon cancer. None of the patients had received any preoperative chemotherapy. Anatomic subsites of tumors were located in the right, cecum and the ascending colon in 28 cases $(27.5 \%)$, in the transverse colon in 7 cases $(6.9 \%)$, in the descending colon in 9 cases $(8.8 \%)$ and in the sigmoid in 58 cases $(56.8 \%)$. Patients were operated with an open or laparoscopic technique and the collected tumor samples were histopathologically staged according to the 6th edition of the TNM classification system as: T1-2N0, 16 cases $(15.7 \%)$; T3-4N0, 39 cases $(38,2 \%)$; T1-4 N1-2, 24 cases (23.5\%); and T1-T4 N0-2M1, 23 cases (22.5\%). According to the differentiation stage of tumors (grade), samples were classified as, well differentiated (low grade), moderately differentiated (intermediate grade) and poorly differentiated (high grade), corresponding to 8 (7.8\%), $74(72,5 \%)$ and $20(19.6 \%)$ patients, respectively. All patients were followed-up for 2 to 68 months, (mean
$38.3 \pm 16.7$ months) and the median follow-up time for all patients was 38 months.

$E$ and D1 cyclin expression in colon cancer patients. Sections were evaluated as either "positive" for cyclin D1, p21 or pRb when the majority of the cells in the selected sections were positively stained compared to the control, normal colon tissue, negative for cyclin D1. Five percent (5\%) was used as the cutoff value as previously published (39-42). For cyclin E and Ki-67, we defined labeling index (LI) (\%) as the percentage of tumor cells which displayed nuclear immunoreactivity. Overall, $64.7 \%$ and $50 \%$ of tissue samples from colon cancer patients were found positive for cyclin D1 and E (Figure 1), respectively. In $22.7 \%$ of cases, cyclin D1 expression was nuclear, $4.5 \%$ cytoplasmic and $72.7 \%$ mixed (cytoplasmic and nuclear localization of cyclin D1). All samples positive for cyclin $\mathrm{E}$ expression revealed a high level of expression (LI $\geq 30 \%$ ), while D1 immunostaining was evaluated as low in 32 out of the 66 cases $(48.5 \%)$, moderate in 24 out of 66 $(36.4 \%)$, and high in 10 out of $66(15.1 \%)$. However, when the pattern and the intensity of cyclin D1 were compared to tumor or patient characteristics (Table I), no correlation was observed. Moreover, no significant association of the cyclin D1 pattern was observed when compared with the Rb expression. 
We further analyzed patient's colon cancers for p21 expression. A total of 48 patients $(47 \%)$ presented a positive staining, however, no significant association between p21 expression and TNM classification, survival rate or $\mathrm{Rb}$ protein expression was detected (Table I). Nevertheless, cyclin E expression was correlated with cyclin D1 $(p=0.038), \mathrm{p} 21 \quad(p=0.047)$, and $\mathrm{Rb}$ expression $(p=0.004)$ (Table II). Among the 64 cases of tumors with cyclin D1 positive staining, 38 of them expressed cyclin E at high levels. Similarly, among the 48 cases with p21 positive tumors, 29 highly expressed cyclin E.

The intensity of $\mathrm{pRb}$ staining (Figure 2) was assessed as low in 27 out of $64(42.2 \%)$, as moderate in 18 out of 64 (28.1\%) and as high in 19 out of 64 cases (29.7\%). Among the 38 cases of tumors with $\mathrm{pRb}$ negative staining, 17 of them were cyclin D1 negative, however this was not statistically significant. However, no relation between $\mathrm{pRb}$ expression and age, tumor location, histological stage, grade, lymph node, liver metastasis and venous invasion was detected.

Follow-up of the patients did not show any effect of cyclin $\mathrm{D} 1$, cyclin $\mathrm{E}$ and $\mathrm{pRb}$ on the 5-year survival rate. Patients with advanced stage disease (stage III and IV) and positive for cyclin D1 were found to have significantly poorer survival rates compared those with a negative cyclin D1 expression $(p=0.009)$. In addition, the survival of patients who were less than 70 years old, was significantly correlated with a positive cyclin D1 expression $(p=0.008)$.

To determine the proliferative capacity of colon cancer cases with abnormal expression of Rb, p21 and cyclins E and D1, we performed immunostaining for Ki-67 (Table III). We observed a statistically significant association between tumor proliferative capacity expressed as Ki-67 labeling index (LI) and positive cyclin D1 staining $(p=0.009)$, positive $\mathrm{pRb}$ staining $(p=0.031)$, and positive $\mathrm{p} 21$ staining $(p=0.050)$. Tumors with low levels of cyclin E expression presented higher Ki-67 LI compared to tumors with high levels of cyclin $\mathrm{E}(p=0.322)$.

Among the 66 tumors positive for cyclin D1 expression, 38 were assessed to have less than $30 \% \mathrm{Ki}-67$ positive cells, and 38 had $\geq 30 \%$. Among the 64 patients presenting $\mathrm{Rb}$ positive tumors, 36 were assessed to have more than $30 \%$ Ki-67 positive cells, and 28 had less than $30 \%(p=0.031)$, (Table III)

\section{Discussion}

In the present study, we have demonstrated the different expression patterns of cyclin D1 and cyclin E in the cell proliferation and clinical outcome of colon cancer. Cyclin D1 expression was positively correlated with cell growth as determined by Ki-67 expression. However, it was not an independent unfavorable prognostic factor. On the other hand,
Table II. Expression of cyclin $E$ in colon cancer patients' samples and correlation with cyclin D1, p21 and pRb expression.

\begin{tabular}{lccc}
\hline & \multicolumn{2}{c}{ Cyclin E } & p-Value \\
\cline { 2 - 3 } & High $^{\mathrm{a}}$ & Low $^{\mathrm{b}}$ & \\
\hline Cyclin D1 & & & \\
Positive & 38 & 28 & 0.038 \\
Negative & 13 & 23 & \\
p21 & & & 0.047 \\
Positive & 29 & 19 & \\
Negative & 22 & 32 & 0.004 \\
pRb & & & \\
Positive & 39 & 25 & \\
Negative & 12 & 26 & \\
\hline
\end{tabular}

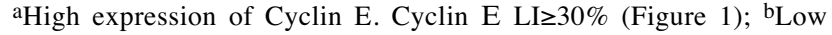
expression of Cyclin E. Cyclin E $\mathrm{LI}<30 \%$.

Table III. Cyclin E, cyclin D1, pRb and p21 and their correlation with $K i-67$ in colon cancer.

\begin{tabular}{|c|c|c|c|c|}
\hline & \multirow[t]{2}{*}{ No } & \multicolumn{2}{|c|}{ Ki-67 } & \multirow[t]{2}{*}{$p$-Value } \\
\hline & & $<30 \%$ & $\geq 30 \%$ & \\
\hline \multicolumn{5}{|l|}{ Cyclin E } \\
\hline $\mathrm{High}^{\mathrm{a}}$ & 51 & 24 & 27 & \multirow[t]{2}{*}{0.322} \\
\hline Low $^{b}$ & 51 & 29 & 22 & \\
\hline \multicolumn{5}{|l|}{ Cyclin D1 } \\
\hline Positive & 66 & 28 & 38 & \multirow[t]{2}{*}{0.009} \\
\hline Negative & 36 & 25 & 11 & \\
\hline \multicolumn{5}{|l|}{$\mathrm{pRb}$} \\
\hline Positive & 64 & 28 & 36 & \multirow[t]{2}{*}{0.031} \\
\hline Negative & 38 & 25 & 13 & \\
\hline \multicolumn{5}{|l|}{$\mathrm{p} 21$} \\
\hline Positive & 48 & 20 & 28 & \multirow[t]{2}{*}{0.050} \\
\hline Negative & 54 & 33 & 21 & \\
\hline
\end{tabular}

aHigh expression of Cyclin E. Cyclin E LI $\geq 30 \%$ (Figure 1); b ${ }^{\mathrm{b}}$ Low expression of Cyclin E. Cyclin E $\mathrm{LI}<30 \%$.

cyclin E expression was not associated neither with the Ki-67 LI nor with clinical outcome. Our study showed that cyclin D1 expression is involved in cell growth and is highly expressed in young colon cancer patients with advanced stage disease, suggesting that it may have a great value in identifying highrisk colon cancer patients. Similarly, in a cohort study of 602 colon cancer cases, cyclin D1 overexpression was associated with a low cancer-specific mortality in Kaplan-Meier analysis ( $p=0.006)$ or in other words with longer survival (43).

Cyclin E, p21 and Rp protein accumulation were not of any significant prognostic value. Cyclin E expression and the cellular marker of proliferation Ki67 have been shown to be 
positively correlated. On the contrary, p2 $7^{\mathrm{kip} 1}$ protein expression and Ki67 were negatively correlated.

These results were closely related to the TNM stage and degree of differentiation. Peculiarly, these results were also associated with prognosis, progression-free survival and median survival.

Although these observations emphasize the importance of cyclins in tumorigenesis and prognosis, the question remains and further studies are needed to further evaluate the role of cyclins on the onset of colon cancer or other malignancies. In conclusion, cyclins can be used as sensitive and accurate markers for the diagnosis of colorectal cancer (37).

\section{Conflicts of Interest}

The Authors declare no conflicts of interest regarding this study.

\section{Authors' Contributions}

PP, GK, DC: conception and design of the study; PP, DC: acquisition of data, drafting the article; ST: histological study, analysis of histological scores; GK, DC: drafting the article, revising it critically for important intellectual content; GK: final approval of the version to be submitted.

\section{Acknowledgements}

This research did not receive any specific grant from funding agencies in the public, commercial, or not-for-profit sectors.

\section{References}

1 Marley AR and Nan H: Epidemiology of colorectal cancer. Int J Mol Epidemiol Genet 7(3): 105-114, 2016. PMID: 27766137.

2 Barchitta M, Maugeri A, Destri GL, Basile G and Agodi A: Epigenetic biomarkers in colorectal cancer patients receiving adjuvant or neoadjuvant therapy: A systematic review of epidemiological studies. Int J Mol Sci 20(15), 2019. PMID: 31390840. DOI: $10.3390 /$ ijms 20153842

3 GLOBOCAN 2018 Graph production. Available at: $\mathrm{http} / /$ gco.iarc. fr/today/online-analysis-map? $\mathrm{v}=2018 \& \operatorname{mode}=$ population\&mode_population=continents\&population=900\&popula tions $=900 \&$ key $=$ asr $\&$ sex $=0 \&$ cancer $=39 \&$ type $=0 \&$ statistic $=5 \&$ prev alence $=0 \&$ population_grou $p=0 \&$ ages_group $\% 5 \mathrm{~B} \% 5 \mathrm{D}=0 \&$ ages_gr oup $\% 5 \mathrm{~B} \% 5 \mathrm{D}=17 \& \mathrm{nb}$ items $=5 \&$ group_cancer $=1 \&$ include_nmsc $=1$ \&include_nmsc_other $=1 \&$ projection $=$ natural - earth $\&$ color palette $=$ default\&map_scale $=$ quantile \&map_nb_colors $=5 \&$ continent $=0 \&$ rotate $=\% 255 \mathrm{~B} 10 \% 252 \mathrm{C} 0 \% 255 \mathrm{D}$

4 Siegel RL, Miller KD and Jemal A: Cancer statistics, 2019. CA Cancer J Clin 69(1): 7-34, 2019. PMID: 30620402. DOI: $10.3322 /$ caac. 21551

5 Yamashita K, Matsuda T, Hasegawa H, Mukohyama J, Arimoto A, Tanaka T, Yamamoto M, Matsuda Y, Kanaji S, Nakamura T Sumi Y, Suzuki S and Kakeji Y: Recent advances of neoadjuvant chemoradiotherapy in rectal cancer: Future treatment perspectives. Ann Gastroenterol Surg 3(1): 24-33, 2019. PMID: 30697607. DOI: $10.1002 /$ ags 3.12213
6 Malumbres M and Barbacid M: Mammalian cyclin-dependent kinases. Trends Biochem Sci 30(11): 630-641, 2005. PMID: 16236519. DOI: 10.1016/j.tibs.2005.09.005

7 Fernandez-Guerra A, Aze A, Morales J, Mulner-Lorillon O, Cosson B, Cormier P, Bradham C, Adams N, Robertson AJ, Marzluff WF Coffman JA and Genevière AM: The genomic repertoire for cell cycle control and DNA metabolism in S. purpuratus. Dev Biol 300(1): 238-251, 2006. PMID: 17078944. DOI: $10.1016 /$ j.ydbio.2006.09.012

8 Ye X, Wei Y, Nalepa G and Harper JW: The cyclin E/Cdk2 substrate p220(NPAT) is required for S-phase entry, histone gene expression, and Cajal body maintenance in human somatic cells. Mol Cell Biol 23(23): 8586-8600, 2003. PMID: 14612403. DOI: $10.1128 / \mathrm{mcb} .23 .23 .8586-8600.2003$

9 Siemeister G, Lucking U, Wengner AM, Lienau P, Steinke W, Schatz C, Mumberg D and Ziegelbauer K: BAY 1000394, a novel cyclin-dependent kinase inhibitor, with potent antitumor activity in mono- and in combination treatment upon oral application. Mol Cancer Ther 11(10): 2265-2273, 2012. PMID: 22821149. DOI: $10.1158 / 1535-7163$.MCT-12-0286

10 Johnson A and Skotheim JM: Start and the restriction point. Curr Opin Cell Biol 25(6): 717-723, 2013. PMID: 23916770. DOI: 10.1016/j.ceb.2013.07.010

11 Bertoli C, Skotheim JM and de Bruin RA: Control of cell cycle transcription during $\mathrm{G}_{1}$ and $\mathrm{S}$ phases. Nat Rev Mol Cell Biol 14(8): 518-528, 2013. PMID: 23877564. DOI: 10.1038/nrm3629

12 Massague J: G1 cell-cycle control and cancer. Nature 432(7015): 298-306, 2004. PMID: 15549091. DOI: 10.1038/nature03094

13 Resnitzky D and Reed SI: Different roles for cyclins D1 and E in regulation of the G1-to-S transition. Mol Cell Biol 15(7): 3463-3469, 1995. PMID: 7791752. DOI: $10.1128 / \mathrm{mcb} .15 .7 .3463$

14 Keyomarsi K and Pardee AB: Redundant cyclin overexpression and gene amplification in breast cancer cells. Proc Natl Acad Sci USA 90(3): 1112-1116, 1993. PMID: 8430082. DOI: 10.1073/pnas. 90.3.1112

15 Buckley MF, Sweeney KJ, Hamilton JA, Sini RL, Manning DL, Nicholson RI, deFazio A, Watts CK, Musgrove EA and Sutherland RL: Expression and amplification of cyclin genes in human breast cancer. Oncogene 8(8): 2127-2133, 1993. PMID: 8336939.

16 Kitahara K, Yasui W, Kuniyasu H, Yokozaki H, Akama Y, Yunotani S, Hisatsugu T and Tahara E: Concurrent amplification of cyclin $\mathrm{E}$ and CDK2 genes in colorectal carcinomas. Int J Cancer 62(1): 25-28, 1995. PMID: 7601562. DOI: 10.1002/ijc.2910620107

17 Keyomarsi K, O'Leary N, Molnar G, Lees E, Fingert HJ and Pardee AB: Cyclin E, a potential prognostic marker for breast cancer. Cancer Res 54(2): 380-385, 1994. PMID: 7903908.

18 Wiman KG: The retinoblastoma gene: role in cell cycle control and cell differentiation. FASEB J 7(10): 841-845, 1993. PMID: 8393817. DOI: $10.1096 /$ fasebj.7.10.8393817

19 Bartek J, Lukas J and Strauss M: A common path to tumor growth. Oncol Rep 3(2): 237-240, 1996. PMID: 21594350. DOI: 10.3892/or.3.2.237

20 Sherr CJ: Cancer cell cycles. Science 274(5293): 1672-1677, 1996. PMID: 8939849. DOI: 10.1126/science.274.5293.1672

21 Harper JW, Adami GR, Wei N, Keyomarsi K and Elledge SJ: The p21 Cdk-interacting protein Cip1 is a potent inhibitor of G1 cyclin-dependent kinases. Cell 75(4): 805-816, 1993. PMID: 8242751. DOI: 10.1016/0092-8674(93)90499-g

22 Muller H, Lukas J, Schneider A, Warthoe P, Bartek J, Eilers M and Strauss M: Cyclin D1 expression is regulated by the 
retinoblastoma protein. Proc Natl Acad Sci USA 91(8): 29452949, 1994. PMID: 8159685. DOI: 10.1073/pnas.91.8.2945

$23 \mathrm{Yu}$ B, Lane ME, Pestell RG, Albanese C and Wadler S: Downregulation of cyclin D1 alters cdk 4- and cdk 2-specific phosphorylation of retinoblastoma protein. Mol Cell Biol Res Commun 3(6): 352-359, 2000. PMID: 11032757. DOI: 10.1006/ mcbr. 2000.0238

24 Geng Y, Eaton EN, Picon M, Roberts JM, Lundberg AS, Gifford A, Sardet C and Weinberg RA: Regulation of cyclin E transcription by E2Fs and retinoblastoma protein. Oncogene 12(6): 1173-1180, 1996. PMID: 8649818.

25 Venter DJ, Bevan KL, Ludwig RL, Riley TE, Jat PS, Thomas DG and Noble MD: Retinoblastoma gene deletions in human glioblastomas. Oncogene 6(3): 445-448, 1991. PMID: 2011399.

26 Bookstein R, Shew JY, Chen PL, Scully P and Lee WH: Suppression of tumorigenicity of human prostate carcinoma cells by replacing a mutated RB gene. Science 247(4943): 712-715, 1990. PMID: 2300823. DOI: 10.1126/science. 2300823

27 Chetty R, Subramoney T, Singh J and Harilal P: Retinoblastoma $(\mathrm{pRb})$ protein immunoexpression in colorectal cancer. Anticancer Res 17(4A): 2593-2597, 1997. PMID: 9252686

28 Gope R, Christensen MA, Thorson A, Lynch HT, Smyrk T, Hodgson C, Wildrick DM, Gope ML and Boman BM: Increased expression of the retinoblastoma gene in human colorectal carcinomas relative to normal colonic mucosa. J Natl Cancer Inst 82(4): 310-314, 1990. PMID: 2405172. DOI: 10.1093/jnci/82.4.310

29 Meling GI, Lothe RA, Borresen AL, Hauge S, Graue C, Clausen OP and Rognum TO: Genetic alterations within the retinoblastoma locus in colorectal carcinomas. Relation to DNA ploidy pattern studied by flow cytometric analysis. Br J Cancer 64(3): 475-480, 1991. PMID: 1911187. DOI: 10.1038/bjc.1991.334

30 Ohtsubo M, Theodoras AM, Schumacher J, Roberts JM and Pagano M: Human cyclin E, a nuclear protein essential for the G1-to-S phase transition. Mol Cell Biol 15(5): 2612-2624, 1995 PMID: 7739542. DOI: $10.1128 / \mathrm{mcb} \cdot 15.5 .2612$

31 Baldin V, Lukas J, Marcote MJ, Pagano M and Draetta G: Cyclin D1 is a nuclear protein required for cell cycle progression in G1. Genes Dev 7(5): 812-821, 1993. PMID: 8491378. DOI: 10.1101/gad.7.5.812

32 Quelle DE, Ashmun RA, Shurtleff SA, Kato JY, Bar-Sagi D, Roussel MF and Sherr CJ: Overexpression of mouse D-type cyclins accelerates G1 phase in rodent fibroblasts. Genes Dev 7(8): 1559-1571, 1993. PMID: 8339933. DOI: 10.1101/gad.7.8.1559

33 Mermelshtein A, Gerson A, Walfisch S, Delgado B, ShechterMaor G, Delgado J, Fich A and Gheber L: Expression of D-type cyclins in colon cancer and in cell lines from colon carcinomas. Br J Cancer 93(3): 338-345, 2005. PMID: 16012517. DOI: 10.1038/sj.bjc.6602709

34 Wangefjord S, Manjer J, Gaber A, Nodin B, Eberhard J and Jirstrom K: Cyclin D1 expression in colorectal cancer is a favorable prognostic factor in men but not in women in a prospective, population-based cohort study. Biol Sex Differ 2: 10, 2011. PMID: 21888663. DOI: 10.1186/2042-6410-2-10
$35 \mathrm{Li} \mathrm{Y,} \mathrm{Wei} \mathrm{J,} \mathrm{Xu} \mathrm{C,} \mathrm{Zhao} \mathrm{Z} \mathrm{and} \mathrm{You} \mathrm{T:} \mathrm{Prognostic} \mathrm{significance}$ of cyclin D1 expression in colorectal cancer: a meta-analysis of observational studies. PLoS One 9(4): e94508, 2014. PMID: 24728073. DOI: 10.1371/journal.pone.0094508

36 Al-Maghrabi J, Mufti S, Gomaa W, Buhmeida A, Al-Qahtani M and Al-Ahwal M: Immunoexpression of cyclin D1 in colorectal carcinomas is not correlated with survival outcome. J Microsc Ultrastruct 3(2): 62-67, 2015. PMID: 30023183. DOI: 10.1016/ j.jmau.2015.01.001

$37 \mathrm{Li} \mathrm{W}$, Zhang G, Wang HL and Wang L: Analysis of expression of cyclin E, p27kip1 and Ki67 protein in colorectal cancer tissues and its value for diagnosis, treatment and prognosis of disease. Eur Rev Med Pharmacol Sci 20(23): 4874-4879, 2016. PMID: 27981549.

38 Fischer AH, Jacobson KA, Rose J and Zeller R: Hematoxylin and eosin staining of tissue and cell sections. CSH Protoc 2008: pdb prot4986, 2008. PMID: 21356829. DOI: 10.1101/pdb.prot4986

39 Michalides R, Hageman P, van Tinteren H, Houben L, Wientjens E, Klompmaker R and Peterse J: A clinicopathological study on overexpression of cyclin D1 and of p53 in a series of 248 patients with operable breast cancer. Br J Cancer 73(6): 728-734, 1996. PMID: 8611372. DOI: $10.1038 /$ bjc.1996.128

40 Palmqvist R, Stenling R, Oberg A and Landberg G: Expression of cyclin D1 and retinoblastoma protein in colorectal cancer. Eur J Cancer 34(10): 1575-1581, 1998. PMID: 9893631. DOI: 10.1016/s0959-8049(98)00162-2

41 Maeda K, Chung Y, Kang S, Ogawa M, Onoda N, Nishiguchi Y, Ikehara T, Nakata B, Okuno $M$ and Sowa M: Cyclin D1 overexpression and prognosis in colorectal adenocarcinoma. Oncology 55(2): 145-151, 1998. PMID: 9499189. DOI: 10.1159/ 000011849

42 Michalides R, van Veelen N, Hart A, Loftus B, Wientjens E and Balm A: Overexpression of cyclin D1 correlates with recurrence in a group of forty-seven operable squamous cell carcinomas of the head and neck. Cancer Res 55(5): 975-978, 1995. PMID: 7867006.

43 Ogino S, Nosho K, Irahara N, Kure S, Shima K, Baba Y, Toyoda S, Chen L, Giovannucci EL, Meyerhardt JA and Fuchs CS: A cohort study of cyclin D1 expression and prognosis in 602 colon cancer cases. Clin Cancer Res 15(13): 4431-4438, 2009. PMID: 19549773. DOI: 10.1158/1078-0432.CCR-08-3330

Received July 8, 2019

Revised September 21, 2019 Accepted September 23, 2019 